Nikolay P. Beschastnov

Doctor of Art History,

Professor of the Department of Drawing and Painting

of the Russian State University of A. N. Kosygin (Technology. Design. Art)

e-mail: npb.art@mail.ru

Moscow, Russia

Evdokia N. Dergiliova

Candidate of Art Criticism,

Associate Professor of the Department of Decorative and Applied Arts and Artistic Textiles of the Russian State University of A. N. Kosygin (Technology. Design. Art)

e-mail: dysua@mail.ru

Moscow, Russia

\title{
MOSCOW METRO OF ALENA DERGILIOVA: IMAGE OF STABILITY AND FEATURES OF CHANGE
}

Summary: The article focuses on the study of graphic works depicting the life of the Moscow metro, created in 1980-1990 by the Moscow artist Alyona Dergiliova. The etchings convincingly reflect the life of our people on the threshold of national historical development. In her complex, variously sized, drawn from life compositions with many figures in motion, the artist mastered the whole range of compositional and visual devices that she would use in her narrative watercolours of the 2000s. She found the contrast of the pathos in the metro interior - stations with a bustling motley crowd of Muscovites deep in themselves and rather shabby travellers from the depths of the Russian backcountry - which became the counterpoint for her further creative search for the image of Moscow. Investigation of resources, experiments in methods of taking the motion of subjects beyond the boundaries of the compositional plane, allow the series to be included in the list of artistic experiments relentlessly carried out by Dergiliova despite the years of difficulties in her creative life.

The theme of 'A Man and His City' is apparently simple but it is resolved in a multitude of complex relationships carried from life on the squares of Moscow over to the interiors of its underground. People above and underground are the same, with their acquired strangeness, yet their psychological state in a confined space is different. The environment - albeit imperceptibly - changes

The metro occupies an extraordinary place in the life of Moscow and all of Russia indeed. It was the first metro system in our country, and numerous visitors along with their children, came to the people. It is vibrant all the same, but in a different way. The architecture inside the metro is closer to the person, and Dergiliova successfully uses this aspect in building her composition. The compositions include many recognizable details of architectural decor which complement the central narrative. These details are clues helping the viewer to figure out its meaning. The characteristic feature of the metro is motion, and the artist draws numerous human figures, figurative stucco elements, sculptural compositions, chips and cracks in the steps, chandeliers swinging at the arrival of the subway train - into an endless cycle.

Scenes depicting the entrances to the metro is a separate theme, which is almost non-existent in Russian art. By rendering the entrances as energy hubs - breaches between the aboveground Moscow and its underground Dergiliova fills them with particular meaning, as all these people, drawn by a skilful and confident hand, will have to squeeze into the endless corridors and noisy subway wagons rattling on rails.

Careful analysis of the artist's creation reveals the disturbing condition of the master's soul. The condition which the masters of art were firmly in for the entire decade after the events depicted in these works.

Keywords: Alena Dergiliova, city, Moscow, metro, composition, etching, graphics, artist, architecture, interior, sculpture, columns, trade, metropolis, urban transport.

city to enjoy the ride on the 'magic stairway'. During the Soviet era, and even now, Russians take long trips through Moscow and, naturally, travel by its 'underground'. 


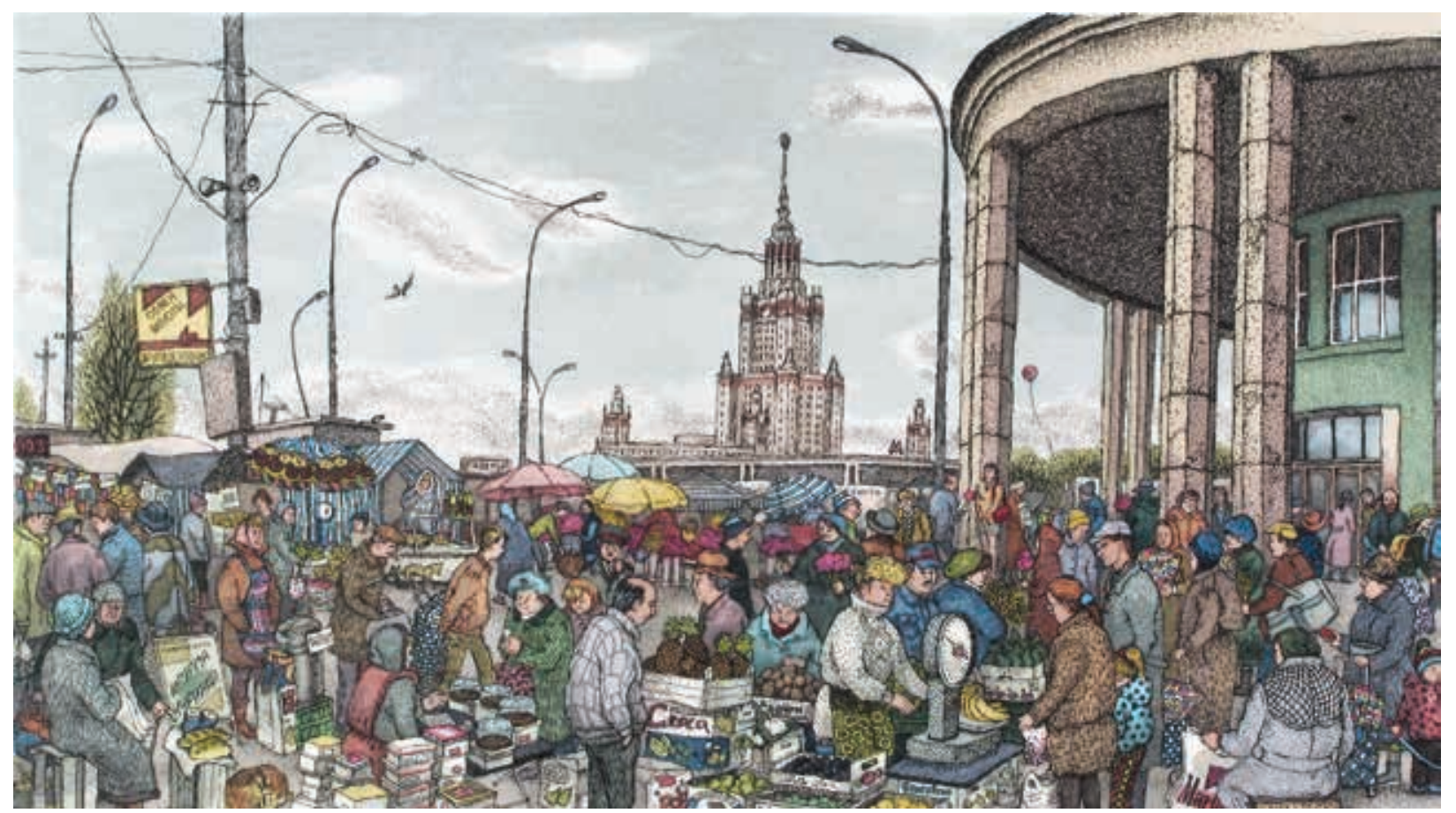

IIl. 1. Alena Dergileva. Universitet metro station. Etching, watercolor. 20×30. 1997

The Moscow metro is the pride of the inhabitants of the metropolis, it simply cannot but be reflected in the fine arts. Paintings and graphic works are regularly displayed at various art exhibitions, sporting the bright letter ' $\mathrm{M}$ ' at underground passages, or depicting faceless flows of people in escalator 'pipes'. These are mostly episodic works built around some scene in the subway that impressed the artist, or the beauty of the interiors of central stations. There are only a few artists who create series works, and Alena Dergiliova is one of the best.

Alena Dergiliova is widely known as the author of large-format watercolours of 'My Moscow' series, in which she reflects the panorama of life of the squares, streets and alleys of our ancient yet rapidly developing city. Her early etching series, less known today, hit the exhibitions at the end of the last century. They became a part of our history and ended up in museum collections. The compositions with the stations of the Moscow metro in these series are one of the most original [1-3].

'Moscow metro' series was completed in the late 1980 s and in the 1990s. It ties up with the artist beginning to explore the hub zones of the 'aura' of the metropolis built above and underground. The Moscow metro is a unique transport artery, conceived as a government-owned system of underground palace-like stations for the public before the Great Patriotic War. Further out from the centre the metro sheds its grandeur, but the stations still gleam with marble and granite. The metro embodies the concepts of motion, movement and change. In the 'chaotic nineties', when many things turned into one big problem, it didn't fail to work properly and brought hope that someday the order would be restored. The metro became not only an extremely reliable workhorse, but also one of the singular symbols of hope for positive changes in Russian society. Everyone was in a hurry, dragging huge bales along the granite steps of the subway, peddling goods above and underground. Metro squares turned into huge flea markets with grocery stalls mingled in as well. Strange-looking people tried to offer you something right in front of the trains and even inside them. The unsettled life has thrown paupers 'robbed' at the train terminal, crippled 'heroes' of all the wars in the world, and homeless people into the subway cars. We did not see them in Soviet Moscow, since the homeless were considered an unemployed class, caught by the police and driven out of the city limits. In the 1990s, half of the country was not paid, homeless people flocked to the underpasses at metro stations gathering into reeking rookeries, previously described in the pre-revolutionary works of V. Gilyarovsky and M. Gorky in scenes on the Khitrov market. But then such rookeries only existed in the dead-ends of unpopular nooks of the city, and presently they reemerged at the popup markets near the metro. Both the active part of the population and completely downtrodden people were drawn to the warmth and the pulse of life. 


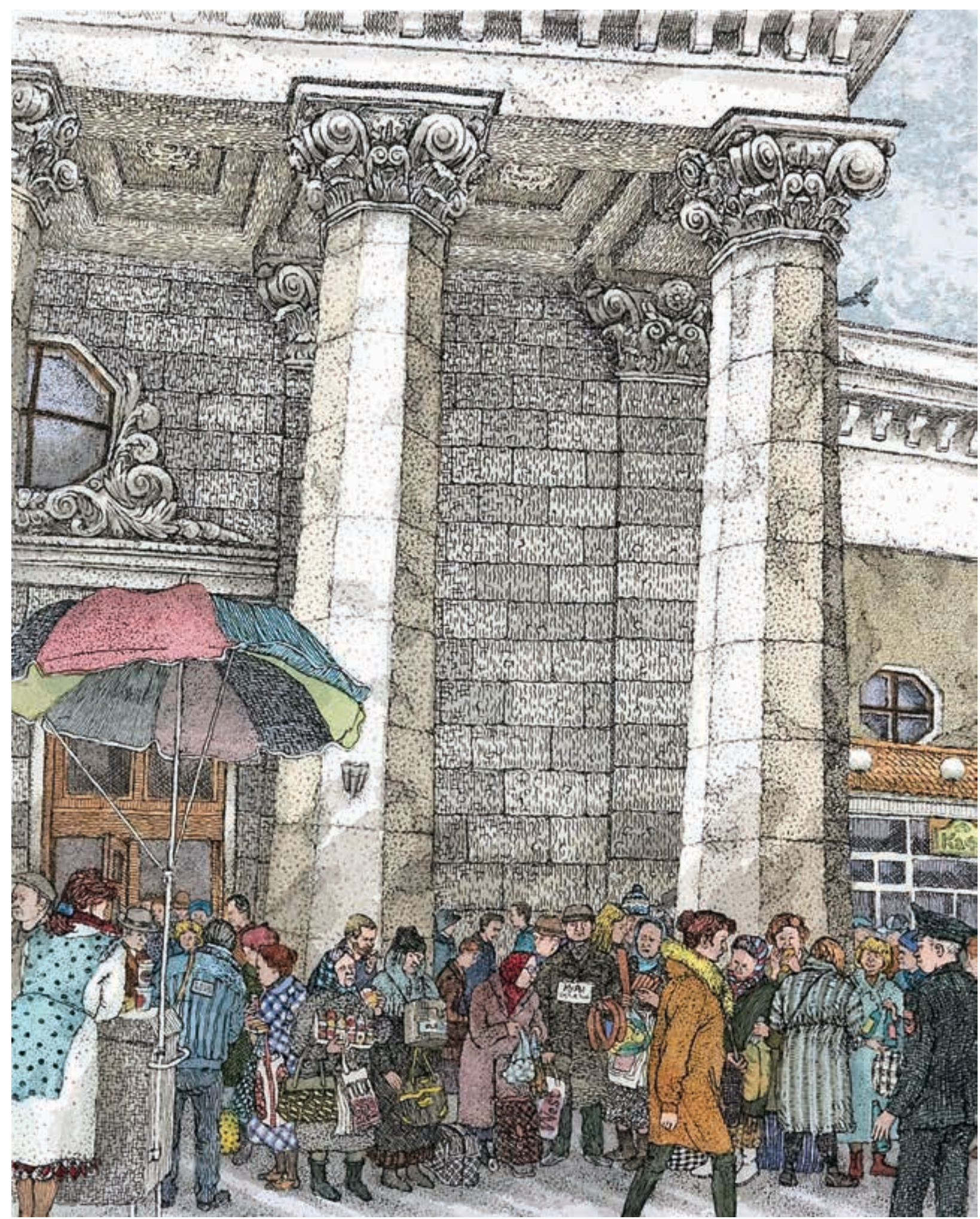

IIl. 2. Alena Dergileva. At the Komsomolskaya metro station. Etching, watercolor. 25.5×20.5. 1997

In 1997 Dergiliova painted one of these markets which was in full swing at the 'Universitet' station. The largest and the most laborious composition in the entire series is 'At the Universitet metro station'. It depicts roughly threescore of our fellow citizens, trading and buying both as of mundane necessity and of dire want on one cold autumn day. The basic trading equipment - boxes on which to sit, lay out the goods and weigh the product. They boxes are also used to carry vegetables and fruits. Most popular goods: bananas, pineapples, potatoes and tomatoes. In those years bananas and pineapples for some reason went at the price of produce from the Russian soil, which was at that time quite surprising 
and frighteningly incomprehensible. People recalling their childhood dreams eagerly bought the exotic fruits. Perhaps that is why the process of procurement of a bunch of bananas by the artist herself is one of the main scenes of the market stretching off into the distance. In fact, we see a collective portrait of the impoverished people of Moscow and cities around it of the late 1990s. Each character is unique, as the composition is based on life sketches.

This cycle of sale and purchase, against the background of a clear sky with white cirrus clouds, is strongly dominated by the columns of the aboveground part of the metro station building, a street pole with loudspeakers and the skyscraper of Moscow State University, which appears almost white due to ambient light and atmospheric conditions. There can be no doubt that all this is happening in Moscow - the capital of our Motherland - with the symbols of sovereignty of the 'Soviet Country' steadfast in their proper places. However, the people's faces in the crowd are far too serious, but the general air is brightened up a little by the vivid colours of beach umbrellas brought from Turkey, used to protect against fleeting, yet very angry rains (Fig. 1).

'At the Komsomolskaya metro station' - an etching in an almost perfectly square shape - is an attempt to take a snapshot of Moscow life at the 'Three Terminals' square. A joint complex consisting of metro stations and three of the country's largest railway terminals lives its own special life of 'trunk and transfer'. Passengers who had got tired of sleeping on the hard bunks of railcars or sitting on the wooden benches of commuter trains, meet an army of hawkers of both sexes and all ages who are selling cigarettes, 'Chicken hot!', hand-made shopping bags with the 'Moscow - 850 years' logo, Krakow sausage and some intoxicating substances as well. Visitors of Moscow hardly making their way through the dense crowd dive into the depths of the metro. One can often miss the glimpse of the cyclopean entrance hall of the Komsomolskaya metro station with its huge capitals somewhere above, apparently meant to amaze the visitor from the outback. Voluminous luggage in the hands of travellers also contributes to the sensations of meeting the capital, transferring most of their thoughts from their heads to the handles of suitcases, bags and trolleys (Fig. 2).

As in the composition 'At the Universitet metro station', Dergiliova uses the method of juxtaposition of the grandiose architecture, which embodies the inviolability of the state, and the vanity of the mundane existence of the common man. But if the first work is a symbol of trading Moscow, the second is of Moscow trading and travelling. The first work is built as a horizontal epic canvas - a bustling sea of people under a huge dome of the sky, the second - as a fragment of an endless human stream. The stream pours out of the picture plane, and the artist 'snatched out' but one of its characteristic sections. We know that the crowd mass spills forth to the platforms near the electric trains and into the 'bowels' of the metro.

Metro stations in the outskirts of Moscow are presented in a series of compositions with halls of 'Prospekt Vernadskogo' and 'Yugo-Zapadnaya'. 'Prospekt Vernadskogo' station is depicted at the beginning of a warm autumn on a Sunday. The premise is typical for the new areas of 'concrete' Moscow: residents of high-rise buildings slowly emerging from the underground, overhead trolley wire suspension cables on pillars, buses, furs and sheepskin coats ads, 'heaping' groups of men of uncertain nationality, women selling fresh bread, apples, peaches and watermelons, and dogs reclining on the warm asphalt. Children playing with balloons, with the coveted McDonald's sign and its golden arches logo echoing the letter M symbol of the metro.

The rectangular glass building of the aboveground hall of 'Yugo-Zapadnaya' station is contrasted by the author to the thick dough of moving people. The market at the station was already in full swing in those years, minibuses parked there bound out to the boroughs, but the modern staggering cycle of people and transport was not there yet. The author lived one stop away from the 'Yugo-Zapadnaya', and she often visited this trade fair which, although a bit dirty, offered relatively high-quality products. It was cheaper than the one at the 'Universitet' because of its location and the significant percentage of workers from former Soviet collective farms. The place was obviously noisy, but the residents loved it, and her local friends asked Dergiliova to capture the scene in its summer and winter shape. To tell the truth, these local friends were foreigners.

In the summer version, the area around the station is presented as a district scale transport hub a peripheral centre of the city. The circular layout of figures at the steps of the station and the complex social composition of the actors are expressions of that. The central part of the composition is occupied by a group of labour people moving towards the en- 


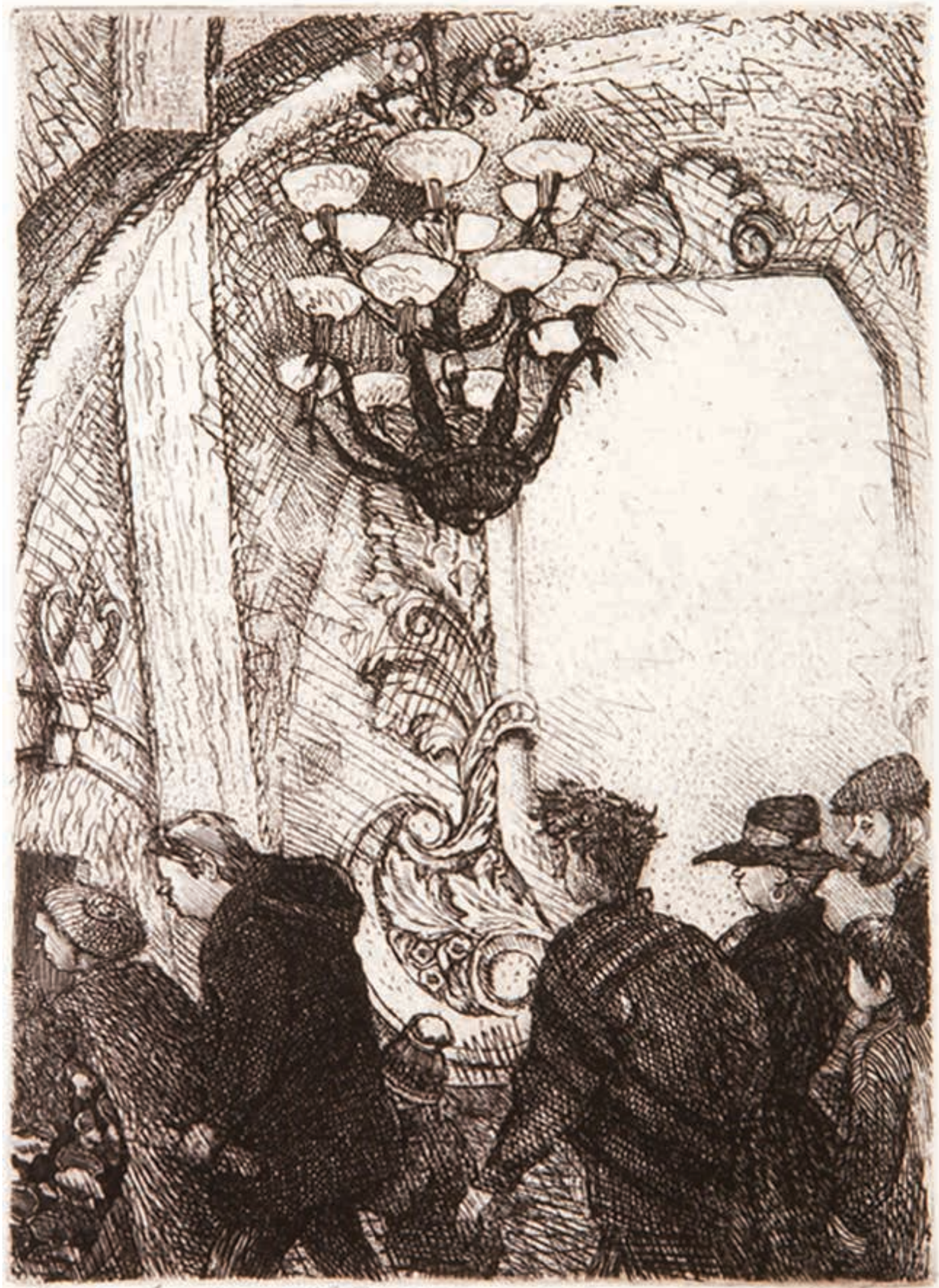

Ill. 3. Alena Dergileva. Arbatskaya metro station. Etching, watercolor. 12×9. 1997

trance of the station. Their figures are made a little larger and more energetic. Dense crowd of elderly people serve as the background, selling plants and flowers grown in their private gardens. Someone is talking on the large cell phone, someone is chewing a pie on the go or dragging a heavy briefcase. The 
winter version is more deserted, and this time you can see the bus stops, their walls covered with tiny bills with various offers. Figures of mindful women in beautiful coats and fur coats with household bags in their hands are clearly outlined against the background of men in bluish padded snow jackets. The women want to be beautiful and, at the same time, feed their family. It's cold, and people try not to linger.

The underground interiors of the subway are depicted in the etchings with the following stations: 'Park Kultury', 'Belorusskaya', 'Arbatskaya', 'Baumanskaya', 'Dinamo', 'Ploschad Revolyutsii', 'Kurskaya' (Fig. 3, 4). Passengers underground are extremely immersed in themselves and detached from the environment. They are alone among the crowd. Someone is struggling to read on the move with varying success, the other one is surprised at the sparrow, which heaven knows how got underground and perched atop the head of a sculpture. But everyone is a part of the endless flow in immense human ducts. Children, old men and women, blooming young ladies and strong men move in the haze of artificial light in fur coats, cloaks, jackets, strange knitted berets and ushanka-hats worn by men and women alike.

The etchings of the 1980s show the average look of the Soviet man from the 'late socialism' period. Men 'over forty' carry 'avoskas', a type of handy fishing net bag, clearly displaying its contents of simple foodstuffs and a fresh newspaper. So what? An honest Soviet man has nothing to hide, although there is nothing to be proud of either...

When you're in a metro wagon and there is no cram, then you have only three types of entertainment: to doze, to read or just flip over the pages, or to eye your fellow travellers unobtrusively. Everyone examines everyone, since Muscovites are very curious by nature. This examination process turns on intuitively as soon as you approach the oversize poster with a map of Moscow metro. The etchings show not a single scene inside the wagon, still you continuously scan the composition, looking for something in front of you. In hundreds of depicted people, Dergiliova's acquaintances recognize their relatives and even themselves, as the author often includes familiar images in their usual setting. Generally, she draws her friends in the background or from the side. It is difficult to recognize them, since these are, of course, not accurate portraits, but typical images, which they acknowledge by saying: 'And I don't have such an old hat!' Of course, they have this hat, but are reluctant to admit that; from the side, it looks cute, but a bit ridiculous.

A special theme in the etching compositions is the plastic relationship between sculptural decoration and living moving people. Our people have changed since the time central station-palaces were built. New artificial and synthetic materials with modified viscose or Lycra actively influenced the plasticity of the dressed figure, gait and even demeanour. In the 1980s, these synthetic clothes were just entering fashion, but the achievements of European and American fashion houses of 2000s finally took root in Russia. However, in subway wagons you can still see young people from the provinces in domestic knitted hats with 'adidas' or 'forward' lettering; as before, plump women are waiting for someone standing next to the sculptures of workers in caps with hard peaks, putting their bags at the labour hero's feet. An image of a police officer is outlined from background of the crowd on 'At the Kurskaya station' etching. Despite his central location, he is also immersed in his 'police' thoughts. Only the stiffness of the figure reveals his 'alert condition', which makes him look at the passengers through the slits of his eyes. 'The horn of abundance' in the form of a column covers the action as a gigantic umbrella. Pre-war and post-war sculpture in the metro lives its own troubled life. Concrete sculptures of partisans with machine guns and marines with pistols greet and accompany Muscovites and visitors of the capital, while dancing couples in light clothes on high reliefs nonchalantly swing among passengers dishevelled by the Moscow weather. 'Stone guests' and their bronze 'friends' have long ceased to bother Muscovites, they even like them... Even such stations, fantastic in terms of the sheer number of sculptures, such as 'Ploschad Revolyutsii', are in the cultural context of the time. The sculpture is in harmony with the architectural exterior ornament that has penetrated the interiors of the metro. Its bold baroque-empire style curls are perceived as elements of the life of giants who once lived. They are disproportionate to the slightly crumpled passengers who jumped out of the subway wagon, both in form and in pathos of content. The author reflects on the existing visual conflict in the 'Metro Arbatskaya' etching, depicting hurrying Muscovites against the background of a huge white high-relief frame, which previously contained the image of Joseph Stalin in the 1950s. It seems that the glow coming from the centre of the image smeared with 


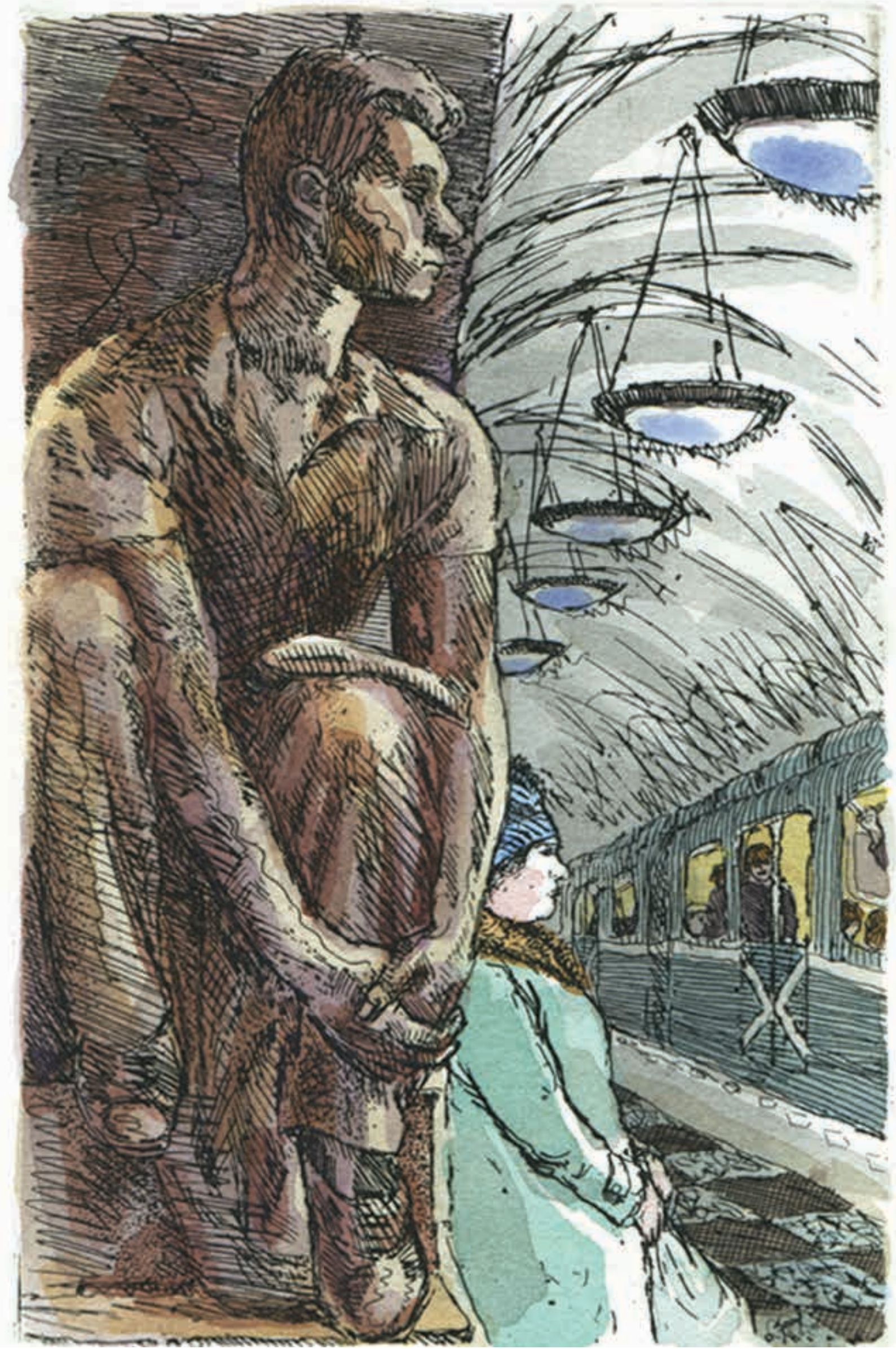

Ill. 4. Alena Dergileva. Ploshchad Revolyutsii metro station. Etching, watercolor. 12×9. 1996 
plaster makes even the descendants of the people who were under Stalin's rule, to shrink and increase their pace.

There is always a lot of provincialism and naivety in Moscow, despite the desire for sophistication. The Moscow merchants threw themselves to the extremes, which was manifested in the eclecticism of architecture. The same fate befell the architecture of the Bolsheviks who moved from St. Petersburg to Moscow, and the metro is the confirmation to this. Cold 'hi-tech' style takes root just as badly in the Moscow subway and demands some time to accustom for the Muscovite's nature. It is most likely, that Moscow traditionally gravitates towards the eclecticism and is not intimidated by sensational diversity. Different cultures and epochs have united in it, and they will be entwined with the sprouts of a new life that is not fully formed yet. The absurd and the awkward, the artistic and the sublime, merging and getting mixed, create nutrient soil for 'the unknown tomorrow'.

They say that you have to be in love with the Moscow metro. It very well may be. After all, if you love, then you forgive many of the original and acquired shortcomings and admire the undoubted advantages. The metro is a reflection of ourselves, restless and naive, conservative and strangely radical, sophisticated and gaudy.

All compositions dedicated to the metro were drawn by Dergiliova on zinc plates directly from life.
To say that drawing in the subway requires a great deal of effort would be almost an understatement. There is simply no room for the artist to work both physically and psychologically. The metro of the last decades of the past century can be compared with the hyper-excited nervous system of a person on the verge of a breakdown. It is simply inconceivable to imagine how it was possible to draw there. But that is just what she did. The analysis of the compositions shows us that they were conceived and executed from life. The fragmentary frame view sections of the underground circulation caught by the author's eye, and multi-textured scenes at the entrance to the metro - were created while she was standing among Muscovites who were stunned by the hardships of life.

Studying the 'underground' etching series of a score of different-sized compositions made by Dergiliova, we can affirm that it was in them that the talent of the graphic artist and the 'scene writer' was most vividly revealed. Scores of people depicted in motion, skilfully drawn into complex compositional constructions of horizontal, diagonal, circular types and their combinations, create that transitional time context, which is read by the viewer as a deeply meaningful text filled with disturbing sensations. This cannot be done after the fact; it can be created only from within the events.

\section{REFERENCES}

1. Beschastnov, N. P. 2020. "Painted Moscow by Alena Dergiliova. City images", Architecture, construction, design, no. 01/02, pp. 102-107.

2. Dergiliova, A. I., A. G. Mitrofanov Moscow: Home Album.- Moscow, which is not there, 2011.- p. 168.

3. Dergiliova, A. I. 2017. Painted Moscow, Moscow, p. 264.

4. Balik, Gökhan, Lökçe, Deniz Balık. 2019. "On the Relationship of Landscape and Painting", AM Journal of Art and Media Studies, no.19, pp. 29-44 DOI: http://dx.doi. org/10.25038/am.v0i19.305 (in English)
5. Häyrynen, Maunu. 2014."Lost Landscapes: Degraded Landscape as Anti-Landscape.", The Anti-Landscape, edited by David E. Nye and Sarah S. Elkind, pp. 149158. Leiden: Rodopi (in English)

6. Somhegyi, Z. 2019. "Pages and Full Stops: On the Aesthetic Relation between Books and Art", AM Journal of Art and Media Studie, no. 19, pp. 69-75. (in English) DOI: http://dx.doi.org/10.25038/am.v0i19.306 
Николай Петрович Бесчастнов

доктор искусствоведения,

профессор кафедры рисунка и живописи

Российского государственного университета им. А. Н. Косыгина

(Технологии. Дизайн. Искусство)

e-mail: npb.art@mail.ru

Россия, Москва

Евдокия Николаевна Дергилёва

кандидат искусствоведения,

доцент кафедры декоративно-прикладного искусства и художественного текстиля

Российского государственного университета им. А.Н. Косыгина

(Технологии. Дизайн. Искусство)

e-mail: dysua@mail.ru

Россия, Москва

DOI: 10.36340/2071-6818-2021-17-2-101-113

\section{МОСКОВСКОЕ МЕТРО АЛЁНЫ ДЕРГИЛЁВОЙ: ОБРАЗ СТАБИЛЬНОСТИ И ЧЕРТЫ ПЕРЕМЕН}

Аннотация: Статья посвящена исследованию графических произведений с изображениями жизни московского метро, созданных в 1980-1990 годах московским художником Алёной Дергилёвой. Офортные листы убедительно отражают жизнь нашего народа в переломный период развития отечественной истории. В разноразмерных отрисованных с натуры сложноорганизованных композициях со множеством движущихся фигур художником был отработан весь спектр композиционно-образных решений, которые она будет использовать в сюжетных акварелях 2000-х годов. Найденный контраст пафоса убранства метро - станций с суетящейся, углублённой в себя разношёрстной толпой москвичей и порядком пообтрепавшихся путешественников из российской глубинки, стал контрапунктом для её дальнейших творческих поисков в изображении Москвы. Ресурсные поиски, эксперименты по приёмам выведения движения людей за границы композиционной плоскости позволяют включить серию в реестр художественных экспериментов, упорно проводившихся Дергилёвой несмотря на тяжелые для творчества годы.

Внешне простая тема «Человек и его город» решается во множестве сложных взаимоотношений, переходящих из жизни на площадях Москвы в интерьеры Москвы подземной. Люди на земле и под землёй одни и те же, со своими благоприобретенными странностями, но их психологическое состояние в замкнутом пространстве уже другое. Среда пусть неуловимо, но меняет человека. Она такая же живая, но другая. В метро архитектура ближе к человеку, и Дергилёва это успешно использует при построении композиций. Композиции включают в себя множество узнаваемых деталей архитектурного убранства, дополняющих основной сюжет. Эти детали - подсказка зрителю при «разгадывании» смысла сюжетного действа. Характерная черта метро движение, и художник вовлекает в бесконечный круговорот множество человеческих фигур, фигурную лепнину, скульптурные композиции, сколы и трещины в ступеньках, качающиеся при прибытии метропоезда светильники.

Отдельной, почти не встречающейся в нашем искусстве темой являются композиции, изображающие входы в метро. Трактуя их как энергетические узлы прорывы между Москвой надземной и подземной, Дергилёва наполняет их особым смыслом, т. к. все эти люди, отрисованные умелой уверенной рукой, должны будут втиснуться в бесконечные коридоры и шумящие, стучащие по рельсам вагоны.

Внимательный анализ созданного художником позволяет увидеть тревожное состояние души мастера. Состояние, которое не отпускало мастеров искусства целое десятилетие после изображённых событий.

Ключевые слова: Алёна Дергилёва, город, Москва, метро, композиция, офорт, графика, художник, архитектура, интерьер, скульптура, колонны, торговля, мегаполис, городской транспорт. 
Метро занимает выдающееся место в жизни Москвы, да и всей России. Оно было первым в нашей стране, и многочисленные гости столицы вместе с детьми приезжали в город ради того, чтобы прокатиться на «лестнице-чудеснице». В советские годы, да и сейчас, россияне осуществляют дальние поездки через Москву и, конечно, проезжают по её «подземке».

Московское метро - гордость жителей мегаполиса, просто не может быть не отражено в изобразительном искусстве. На художественных выставках периодически экспонируются картины и графические листы с изображениями яркой буквы «М» у подземных переходов или безликим людским потоком в «трубах» эскалаторов. В основном это эпизодические произведения, построенные на поразившей художника сцене в метро или красоте интерьеров центральных станций. Мастеров, создающих серии работ, немного, и один из лучших - Алёна Дергилёва.

Алёна Дергилёва широко известна как автор большеформатных акварелей «Моя Москва», в которых панорамно отражена жизнь площадей, улиц и переулков нашего древнего и быстроразвивающегося города. Менее известны сегодня её ранние офортные серии, которые прошли по выставкам в конце ушедшего века, стали частью нашей истории и осели в музейных собраниях. Композиции со станциями московского метро в этих сериях одни из самых оригинальных [1-3].

Серия «Московское метро» была исполнена в конце 1980-х -1990-е годы и связана с началом художнического изучения автором узловых зон «ауры» построенного на земле и под землей мегаполиса. Московское метро - уникальная транспортная артерия, задуманная как государственная система подземных дворцов-станций для народа ещё до Великой Отечественной войны, приближаясь к окраинам Москвы, теряет помпезность, но по-прежнему сверкает мрамором и гранитом. Метро - олицетворение движения, перемещения, изменения... В «лихие девяностые», когда многое превратилось в одну большую проблему, оно работало бесперебойно и порождало надежду на восстановление порядка. Метро стало не только сверхнадёжной рабочей лошадкой, но и одним из своеобразных символов надежды на положительные изменения в российском обществе. Все куда-то спешили, тащили огромные тюки по гранитным ступенькам подземки, торговали с рук на земле и под землёй. Площади у метро преврати- лись в огромные барахолки, смешанные с продуктовыми рынками. Странного вида люди пытались что-то предлагать даже у метровагонов и в самих вагонах. Неустроенность жизни выплеснула в вагоны метро попрошаек, «обворованных» на вокзале, «героев»-инвалидов всех войн на свете и «бомжей». Мы их не видели в советской Москве, так как «бомжи», как неработающий контингент, отлавливались милицией и выдворялись за городскую черту. В 1990-е годы не получала зарплату добрая половина страны, и в переходах у метро стали образовываться смрадные «бомжележки», зафиксированные в дореволюционной литературе В. Гиляровским и М. Горьким в сценах на «Хитровом рынке». Но тогда они существовали в тупиковых-»неходовых» углах города, а теперь возродились у стихийных рынков у метро. Активная часть населения и полностью опустившиеся люди тянулись к биению жизни и теплу.

Один из таких рынков, кипевших у метро «Университет», Дергилёва нарисовала в 1997 году. Композиция «У станции метро «Университет» является наиболее крупной и многодельной из всей серии. На ней изображено около шестидесяти наших соотечественников, торгующих и покупающих как по жизни, так и по жестокой нужде холодным осенним деньком. Основной торговый инвентарь - ящики, на которых сидят, раскладывают товар и производят взвешивание продукта. В них же подтаскивают овощи и фрукты. Самый ходовой товар: бананы, ананасы, картошка и помидоры. Бананы и ананасы почему-то стали в те годы «идти» по цене даров земли российской, что было тогда удивительно и пугающе непонятно. Помня о мечтах детства, их покупали бойко. Возможно, поэтому процесс приобретения связки бананов самим художником является одной из главных сцен уходящего вдаль торгового пространства. По сути, перед нами коллективный портрет уже достаточно обнищавшего московского и подмосковного люда конца 1990-х. Каждое действующее лицо - индивидуально, так как композиция строится на основе натурных зарисовок.

Над всем этим круговоротом купли-продажи на фоне чистого неба с белыми перистыми облачками мощно доминируют колонны наземной части метростанции, столб с громкоговорителями и почти белое из-за состояния световоздушной среды высотное здание МГУ. Сомнений нет, всё это происходит в столице нашей Родины Москве и символы государственности «Страны 
Советов» стоят на своих местах непоколебимо. Народ, правда, излишне сосредоточен, но зато ситуацию немного скрашивают привезённые из Турции яркие цвета пляжных зонтов, используемых для защиты от скоротечных, но очень злых дождей (рис. 1).

Почти квадратный офорт «У метро «Комсомольская» - попытка запечатлеть жизнь Москвы у «трёх вокзалов». Единый, никогда не спящий комплекс из метростанций и трёх крупнейших железнодорожных вокзалов страны живёт своей особой «чемоданно-пересадочной» жизнью. Пассажиры, уставшие от спанья на жёстких койках вагонов или сидения на деревянных скамьях пригородных электричек, встречаются армией лоточников и лоточниц разных возрастов, продающих сигареты, «куры горячие», самошвейные хозяйственные сумки с надписью «Москва - 850 лет», краковскую колбасу и даже что-то горячительное. Гости Москвы с трудом продираются через плотную толпу и ныряют в глубину метро. Циклопический наземный вестибюль метростанции «Комсомольская» с огромными капителями где-то наверху, призванный, видимо, поразить приезжего из глубинки, как правило, остаётся незамеченным. Свой вклад к ощущениям встречи со столицей вносит и объёмный багаж в руках путешественников, перенося основную часть мыслей из головы к ручкам чемоданов, сумок и тележек (рис. 2).

Как и в композиции «У метро «Университет», Дергилёва использует приём противопоставления величественной архитектуры, олицетворяющей незыблемость державы, и суетности обыденного существования обывателя. Но если первая работа - символ Москвы торгующей, то вторая Москвы торгующей и путешествующей. Первая работа построена как горизонтальное эпическое полотно - людское суетное море под огромным куполом неба, второе - как фрагмент бесконечного потока людей. Поток выливается за пределы картинной плоскости, и художник «выхватил» только один из характерных его участков. Мы знаем, что столпотворение продолжается как на перронах у электричек, так и в «чреве» метро.

Окраинные станции метрополитена представлены в серии композициями с вестибюлями метро «Проспект Вернадского» и «Юго-Западная». Метро «Проспект Вернадского» изображено в начале тёплой осени в воскресенье. Ситуация типична для новых районов «бетонной» Москвы: неспеш- но выходящие из-под земли жители многоэтажек, троллейбусные растяжки на столбах, автобусы, реклама мехов и дублёнок, «кучкующиеся» группы мужчин непонятной национальности, торгующие свежим хлебом, яблоками, персиками и арбузами женщины и собаки, возлежащие на тёплом асфальте. Играющие с воздушными шариками дети, с модной тогда надписью «Макдональдс» и логотипом «М», похожим на метро-символику.

Прямоугольная стекляшка наземной части метро «Юго-Западная» противопоставлена автором плотному замесу движущихся людей. В те годы у станции уже бойко торговал рынок, и стояли маршрутки, уходящие в область, но современного ошеломляющего круговорота людей и транспорта ещё не было. Автор, проживая на расстоянии одной остановки от «Юго-Западной», часто посещала грязноватый, но с довольно качественными продуктами торговый развал. Он был дешевле, чем у метро «Университет» из-за своего расположения и наличия значительного процента колхозников. Место явно шумноватое, но оно нравилось жителям, и подруги, живущие в этом районе, попросили Дергилёву запечатлеть ситуацию в летнем и зимнем состоянии, правда, подруги эти - иностранки.

В летнем варианте площадка у метро подана как транспортная развязка районного масштаба - периферийный центр города. Это выражено в кольцевой компоновке фигур у ступенек станции и сложном социальном составе действующих лиц. Центральную часть композиции занимает группа трудоспособного населения, движущегося ко входу в метро. Их фигуры сделаны несколько крупнее и энергичнее. Фоном для них служат плотные ряды пенсионеров, подторговывающих растительно-цветочной продукцией со своих огородов. Кто-то звонит по большого размера сотовому телефону, кто-то жуёт на ходу пирожок или тащит тяжеленный портфель. Зимний вариант более пустынен, и уже можно разглядеть автобусные остановки, оклеенные народом листочками с текстами с различными предложениями. На фоне синеватых синтепоновых курток мужчин хорошо читаются фигуры заботливых женщин в красивых пальто и шубах с хозяйственными сумками в руках. Им хочется быть красивыми и, одновременно, кормить семью. Холодно, и люди стараются не задерживаться.

Подземные интерьеры метро запечатлены в офортах со станциями: «Парк Культуры», 
«Белорусская», «Арбатская», «Бауманская», «Динамо», «Площадь Революции», «Курская» (рис. 3, 4). Пассажиры под землёй предельно погружены в себя и отрешены от среды. Они одиноки среди толпы. Кое-кто с переменным успехом силится читать на ходу или дивиться воробью, невесть как попавшему под землю и севшему на голову скульптуре, но все они - часть бесконечного потока в огромных людских путепроводах. Дети, старики, старухи, цветущие молодые женщины и крепкие мужчины движутся в мареве искусственного света в шубах, пальто, куртках, странных вязаных беретах и одетых как на мужчин, так и женщин шапках-ушанках.

По офортам 1980-х годов можно составить внешний облик советского человека периода «позднего социализма». В руках мужчин «за сорок» встречаются сумки-»авоськи» в виде рыболовной сетки, в которых хорошо просматривается вся нехитрая снедь и свежая газета. А что? Советскому человеку нечего скрывать, хотя и гордиться тоже особенно нечем...

Когда едешь в вагоне метро без давки, то у тебя есть всего три развлечения: дремать, читать и листать прессу или ненавязчиво разглядывать попутчиков. Разглядывают все, так как москвичи очень любопытны по своей природе. Этот процесс разглядывания интуитивно включается, как только подходишь к листам с изображениями схем метро. В офортах нет ни одной сцены в вагоне, но ты непрерывно сканируешь композицию, что-то выискивая напротив себя. В сотнях изображённых людей знакомые Дергилёвой находят своих родственников и даже себя, так как автор часто вставляет изученные образы в привычную им обстановку. Как правило, подруги и друзья изображаются на втором плане или в повороте. Их трудно узнать, так как это, конечно, не портреты, а типизированные образы, но узнают со словами: «А у меня такой старой шапочки нет!» Шапочка-то есть, но трудно признаться, что она, при взгляде со стороны, смотрится мило, но нелепо.

Особая тема в офортных композициях - пластические взаимосвязи скульптурного убранства и живых движущихся людей. Со времён постройки центральных станций-дворцов наши люди изменились. Новые искусственные и синтетические материалы с модифицированной вискозой или «лайкрой» активно повлияли на пластику одетой фигуры, походку и даже манеру поведения. В 1980-е эта одежда из синтетики ещё только входила в жизнь, но в двухтысячные достижения европейских и американских домов мод окончательно прижились в России. Однако по-прежнему в вагонах можно увидеть молодых людей из провинции в трикотажных головных уборах отечественной вязки с надписью «adidas» или «forward», по-прежнему рядом со скульптурами рабочих в кепках с жесткими козырьками кого-то ожидают, поставив сумки у ног героя труда, полноватые женщины. В офорте «На станции «Курская» из толпы выделено изображение милиционера. Несмотря на центральное место его расположения, он также погружён в свои «милиционерские» мысли. Только скованность фигуры выдаёт его «рабочее состояние», позволяющее смотреть на пассажиров сквозь щёлочки глаз. «Рог изобилия» в виде колонны накрывает всё действо гигантским зонтиком. Довоенная и послевоенная скульптура в метро живёт своей тревожной жизнью. Бетонные изваяния партизан с автоматами и матросов с пистолетами встречают и провожают москвичей и гостей столицы, а танцующие пары в лёгкой одежде на горельефах невозмутимо кружатся среди взъерошенных московской непогодой пассажиров. «Каменные гости» и их бронзовые «друзья» уже давно не смущают москвичей, и они им уже нравятся... Даже такие фантастические по количеству скульптур станции, как «Площадь Революции» входят в контекст культуры времени. Скульптуре созвучен архитектурный экстерьерный орнамент, проникший в интерьеры метро. Его мощные барочно-ампирные завитки воспринимаются как элементы быта живших когда-то великанов. Они несоразмерны выскочившим из метро-вагонов слегка помятым пассажирам ни формой, ни патетикой содержания. Имеющийся зрительный конфликт автор отражает в офорте «Метро Арбатская», изображая спешащих москвичей на фоне огромной белой горельефной рамы, в которой ещё в 1950-е годы красовалось изображение И. В. Сталина. Кажется, что свечение, идущее от центра замазанного штукатуркой изображения, заставляет съёживаться и ускорять шаг даже потомков бывшего в его власти народа.

В Москве всегда много провинциальности и наивности, несмотря на стремление к утончённости. Московское купечество бросало в крайности, что проявилось в эклектичности архитектуры. Та же участь постигла архитектуру переехавших из Питера в Москву большевиков, и метро этому 
подтверждение. Холодный «хай-тек» так же плохо приживается в московской подземке и требует привязки к характеру москвича. Скорее всего, Москва традиционно тяготеет к эклектике и пестрота ощущений её не пугает. Разные культуры и времена соединились в ней, и будут соединяться ростками новой ещё не до конца сформировавшейся жизни. Нелепое и несуразное, художественное и высокое, сливаясь и перемешиваясь, создают питательную почву для «неизвестного завтра».

Говорят, что московское метро нужно любить. Возможно. Ведь если любишь, то прощаешь многие изначальные и благоприобретенные недостатки и восхищаешься несомненными достоинствами. Метро - отражение нас самих, беспокойных и наивных, консервативных и странно радикальных, утончённых и аляповатых.

Все композиции, посвящённые метро, отрисованы Дергилёвой на цинковых пластинах непосредственно с натуры. Сказать, что рисование в метро требует огромного напряжения - почти ничего не сказать. Работе художника там просто нет места ни физически, ни психологически. Ме- тро последних десятилетий ушедшего века можно сравнить с перевозбуждённой нервной системой человека на грани срыва. Как там можно было рисовать, представить невозможно. Но это было. Анализ композиций показывает нам, что они задуманы и исполнены натурно. Выхваченные взглядом фрагментарные ракурсные участки подземного круговорота, многофактурные сцены у входа в метро - созданы стоя среди ошалевших от тягот жизни москвичей.

Изучая сделанную Дергилёвой офортную «подземную» серию из двух десятков разноразмерных композиций, можно сказать, что именно в них наиболее ярко выявился талант рисовальщика и «сюжетника». Множество изображённых в движении людей, мастерски отрисованных в сложные композиционные построения горизонтального, диагонального, кольцевого типов или их сочетаний, создают тот контекст переходного времени, который читается зрителем как глубоко содержательный, наполненный тревожными ощущениями текст. Этого не сделать по прошествии времени, это создаётся только внутри событий.

\section{БИБЛИОГРАФИЯ}

1. Бесчастнов Н. П. Нарисованная Москва Алёны Дергилёвой. Образы города // Архитектура, строительство, дизайн. - № 01/02. - 2020. - С. 102-107.

2. Дергилёва А. И., Митрофанов А. Г. Москва: Домашний альбом. - М.: Москва, которой нет, 2011. - 168 c.

3. Дергилёва А.И. Нарисованная Москва.- М.: Контакт-культура, 2017.- 264 с.

4. Balik, Gökhan, Lökçe, Deniz Balık. 2019. «On the Relationship of Landscape and Painting», AM Journal of Art and Media Studies, no.19, pp. 29-44 DOI: http:// dx.doi.org/10.25038/am.v0i19.305

5. Häyrynen, Maunu. 2014.»Lost Landscapes: Degraded Landscape as Anti-Landscape.», The Anti-Landscape, edited by David E. Nye and Sarah S. Elkind, pp. 149158. Leiden: Rodopi

6. Somhegyi, Z. 2019. «Pages and Full Stops: On the Aesthetic Relation between Books and Art», AM Journal of Art and Media Studie, No. 19, pp. 69-75. DOI: http:// dx.doi.org/10.250 